Tropical Journal of Pharmaceutical Research December 2018; 17 (12): 2405-2411

ISSN: 1596-5996 (print); 1596-9827 (electronic) (1) Pharmacotherapy Group, Faculty of Pharmacy, University of Benin, Benin City, 300001 Nigeria.

\title{
Pumilaside A from Litchi semen induces apoptosis in human gastric cancer BGC823 cells via activation of death receptor- and mitochondria-mediated apoptotic pathways
}

\author{
Xiao Zheng ${ }^{1}$, Jian-Wei Liang ${ }^{1}$, Gang Cui ${ }^{1}$, Lei Zhang ${ }^{2}$, Jun Liu ${ }^{1 *}$ \\ ${ }^{1}$ Department of General Surgery, ${ }^{2}$ Department of Cardiothoracic Surgery, Taian City Central Hospital, Taian 271000, PR China \\ *For correspondence: Email: junliuta@163.com
}

Sent for review: 10 February 2018

Revised accepted: 19 November 2018

\begin{abstract}
Purpose: To investigate the cytotoxic effect of pumilaside $A$ from Litchi semen against human gastric cancer BGC823 cells, and unravel its possible mechanism(s) of action.

Methods: The cytotoxic activity of pumilaside A (5 - $40 \mu \mathrm{g} / \mathrm{mL}$ ) against BGC823 cells was assessed by thiazolyl blue tetrazolium bromide assay. The pro-apoptotic effect of PA (10, 20 or $40 \mu \mathrm{g} / \mathrm{mL}$ ) on BGC823 cells was monitored by flow cytometry, while the mechanisms involved were investigated using western blot.

Results: Pumilaside A significantly produced cytotoxic activity against BGC823 cells $\left(I C_{50}=25.43\right.$ $\mu \mathrm{g} / \mathrm{mL})$ and induced apoptosis in BGC823 cells $(p<0.01)$. Treatment with pumilaside $A$ led to significant upregulation of pro-apoptotic factors (Fas, FasL, FADD, Bax, Apaf-1, and c-caspase -8, 9 and 10), and downregulation of anti-apoptotic factors (survivin and Bcl-2, $p<0.05,0.01$ ). In addition, pumilaside $A$ increased the cytoplasmic levels of Smac and cytochrome $c$ in BGC823 cells by enhancing their mitochondrial release, and significantly upregulated the levels of executioner c-caspases-3, 6 and 7 ( $p<$ $0.05,0.01)$.

Conclusion: Pumilaside A shows good cytotoxic activity against BGC823 cells via a mechanism related to activation of death receptor- and mitochondria-mediated apoptotic pathways. Thus, pumilaside $A$ has a potential for use as an anti-gastric cancer agent.
\end{abstract}

Keywords: Litchi semen, Pumilaside A, BGC823 cells, Cytotoxicity, Apoptosis

\begin{abstract}
This is an Open Access article that uses a funding model which does not charge readers or their institutions for access and distributed under the terms of the Creative Commons Attribution License (http://creativecommons.org/licenses/by/4.0) and the Budapest Open Access Initiative (http://www.budapestopenaccessinitiative.org/read), which permit unrestricted use, distribution, and reproduction in any medium, provided the original work is properly credited.

Tropical Journal of Pharmaceutical Research is indexed by Science Citation Index (SciSearch), Scopus, International Pharmaceutical Abstract, Chemical Abstracts, Embase, Index Copernicus, EBSCO, African Index Medicus, JournalSeek, Journal Citation Reports/Science Edition, Directory of Open Access Journals (DOAJ), African Journal Online, Bioline International, Open-J-Gate and Pharmacy Abstracts
\end{abstract}

\section{INTRODUCTION}

At present, gastric cancer is the second leading cause of cancer death, and ranks fourth in global cancer prevalence [1,2]. Surgery, interventional therapy, radiotherapy, chemotherapy and biotherapy constitute the main treatment strategies for gastric carcinoma [3-6]. It has been suggested that chemotherapy is a vital aspect of this treatment [7]. Prolonged use of chemotherapy drugs by gastric cancer patients is necessary to enhance therapeutic outcomes. However, prolonged use of these drugs is associated with development of drug resistance by the cancer cells, leading to reduced effectiveness of chemotherapy [8]. Thus, it is crucial to evolve newer and more effective chemotherapy drugs for treating gastric cancer. 
Anticancer drugs from Chinese medicine have attracted the interest of researchers in the past decades [9].

It has been reported that litchi semen, the seeds of Litchi chinensis Sonn. (Sapindaceae family), exerts anticancer, radical-scavenging and antioxidant activities [10-12]. Pumilaside A (PA), a sesquiterpene glucoside from litchi semen, has been shown to exert cytotoxic activity against some cancer cells, but the mechanisms of action are not yet understood [13].

The aim of the present study was to investigate the cytotoxic activity of PA against human gastric cancer BGC823 cells using thiazolyl blue tetrazolium bromide (MTT) assay. The cytotoxic mechanisms of PA against BGC823 cells were also studied by monitoring apoptosis and apoptosis-related proteins using flow cytometric and western blot procedures.

\section{EXPERIMENTAL}

\section{Plant material}

Litchi semen was obtained from Anguo Chinese herbal medicine shop in 2015 and authenticated by Jun Liu, a taxonomist in the Department of General Surgery, Taian City Central Hospital. A voucher specimen (voucher no. TACCH DP20150481) was kept in the Department of Pharmacy, Taian City Central Hospital for future reference.

\section{Chemicals and reagents}

All solvents used in this study were of analytical grade, and were purchased from Haiyang Chemical Co. (Qingdao, China). Diaion HP-20 macroporous resin was product of Mitsubishi Chemical Co., Japan. Fetal bovine serum (FBS) and RPMI-1640 medium were products of Gibco Life Technologies (Grand Island, NY, USA), while MTT and dimethyl sulfoxide (DMSO) were products of Sigma (St. Louis, MO, USA). Kits for enhanced BCA protein assay and Annexin VFITC/PI apoptosis assay were supplied by Beyotime Biotechnology (Haimen, China) and JRDUN Biotech (Shanghai, China), respectively. Total, cytoplasmic and mitochondrial protein extraction kits were purchased from BioDee (Beijing, China), Nanjing Biobox Biotech (Nanjing, China) and Bangyi-bio (Shanghai, China), respectively. Polyvinylidene fluoride (PVDF) membrane was obtained from Roche Diagnostics (Mannheim, Germany). Primary antibodies against Fas, FasL, FADD, Bax, Bcl-2, Survivin, Apaf-1, cytochrome c, Smac, cleaved (c)-caspases-8, 10, 9, 3, 6 and 7, as well as $\beta$ - actin and COX IV were supplied by cell Signaling Technology (Beverly, MA, USA), Abcam (Cambridge, UK) or Sigma (St. Louis, MO, USA). HRP-conjugated antibody was product of Jackson Immuno Research Laboratories (West Grove, Pennsylvania, USA).

\section{Extraction and isolation of PA}

Litchi semen $(10 \mathrm{~kg})$ was finely ground and extracted thrice with $15 \mathrm{~L} 95 \%$ ethanol at $30^{\circ} \mathrm{C}$ for 4 days. The extract was dried using lowpressure evaporation to yield $1735 \mathrm{~g}$ of material, which was subsequently dissolved in water and then successfully subjected to partitioning in a solvent mixture of petroleum ether, ethyl acetate and n-butyl alcohol. The faction from n-butyl alcohol (208 g) was applied to a column of Diaion HP-20 resin eluted with water and methanol to afford a methanol eluate $(113 \mathrm{~g})$. This was purified further using silica gel column chromatography eluted with chloroform: methanol at volume ratios in the range 90:10 $60: 40$. Eluates from chloroform: methanol (85:15 and 80:20) were pooled and subjected to repetitive silica gel column chromatography to obtain $35 \mathrm{mg}$ of PA. Thereafter, mass spectrometry, NMR and HPLC were used for structural elucidation and purity assessment of the PA.

\section{Cell culture}

BGC823 cell line was obtained from ATCC (Manassas, VA, USA). The cells were maintained at $37{ }^{\circ} \mathrm{C}$ on RPMI-1640 medium containing $100 \mathrm{U} / \mathrm{mL}$ penicillin, $100 \mathrm{U} / \mathrm{mL}$ streptomycin and $10 \%$ FBS in a humidified incubator with $5 \% \mathrm{CO}_{2}$.

\section{Cell viability assay}

MTT assay was carried out to assess the cytotoxic activity of PA against BGC823 cells. In this procedure, the BGC823 cells $\left(5 \times 10^{3}\right.$ cells/well) were seeded in 96-well plates for $24 \mathrm{~h}$. Thereafter, the cells were exposed to varying doses of PA $(0,5,10,15,20,25,30,35$ or 40 $\mu \mathrm{g} / \mathrm{mL}$ ) for $48 \mathrm{~h}$, following which $50 \mu \mathrm{L}$ of 2 $\mathrm{mg} / \mathrm{mL}$ solution of MTT was introduced into each well. The plates were subjected to incubation for $4 \mathrm{~h}$ at $37^{\circ} \mathrm{C}$, at the end of which the RPMI- 1640 medium was removed, and the cells were incubated with $200 \mu \mathrm{L}$ DMSO in the dark for 30 min to dissolve the resultant blue-violet formazan crystals. The absorbance values of the formazan solutions were read in a Bio Rad microplate reader (Model 680, USA) at $570 \mathrm{~nm}$ against a blank of DMSO $[14,15]$. 


\section{Cell apoptosis assay}

The BGC823 cells $\left(5 \times 10^{5}\right.$ cells/well $)$ were seeded in 12-well plates for $24 \mathrm{~h}$ and treated with PA $(0,10,20$ or $40 \mu \mathrm{g} / \mathrm{mL})$ for $48 \mathrm{~h}$, followed by harvesting and washing (thrice) in chilled PBS, and staining with Annexin V-FITC/PI. The stained cells were then subjected to flow cytometric analysis using FACSCalibur from BD Biosciences (San Jose, CA, USA) [16].

\section{Western blot assay}

Following treatment with PA $(0,10,20$ or 40 $\mu \mathrm{g} / \mathrm{mL}$ ) for $48 \mathrm{~h}$, BGC823 cells were harvested, and their total, cytoplasmic and mitochondrial protein contents were separately extracted with the appropriate kits. The total protein was used to investigate the expressions of Fas, FasL, FADD, Bax, Bcl-2, survivin, Apaf-1, and ccaspases-8, 10, 9, 3, 6 and 7 proteins. The cytoplasmic and mitochondrial proteins were used to investigate the release of mitochondrial cytochrome c and Smac proteins into the cytoplasm compartment.

Protein concentration was determined using enhanced BCA kits in line with the kit protocol [17]. The protein $(40 \mu \mathrm{g})$ was subjected to SDSpolyacrylamide gel electrophoresis, and the resultant bands were transferred onto PVDF membrane. Non-specific binding was blocked using $5 \%$ non-fat milk, prior to incubation of the membrane overnight at $4{ }^{\circ} \mathrm{C}$ with the appropriate primary antibodies, and subsequently with HRPconjugated antibody for $2 \mathrm{~h}$ at room temperature. Finally, the protein bands were subjected to chemiluminescence analysis. In this assay, $\beta$ actin served as endogenous control for total protein and cytoplasmic protein [18], while COX IV served as endogenous control for mitochondrial protein.

\section{Statistical analysis}

The results obtained are presented as mean \pm standard deviation (SD). Statistical differences among groups were determined by one-way analysis of variance (ANOVA). All statistical analyses were carried out using SPSS version 21.0 (SPSS Inc., Chicago, IL, USA). Values of $p$ $<0.05$ were assumed to indicate statistical significance.

\section{RESULTS}

\section{Purity and identification of PA}

Results from mass spectrometry indicated that the molecular formula of the target analyte, an amorphous powder, was $\mathrm{C}_{21} \mathrm{H}_{39} \mathrm{O}_{8}$. Comparing NMR data of the target analyte with existing literature [19], it was identified as PA (Figure 1). Results from HPLC area normalization method indicated that the level of purity of PA was 98.3 $\%$.

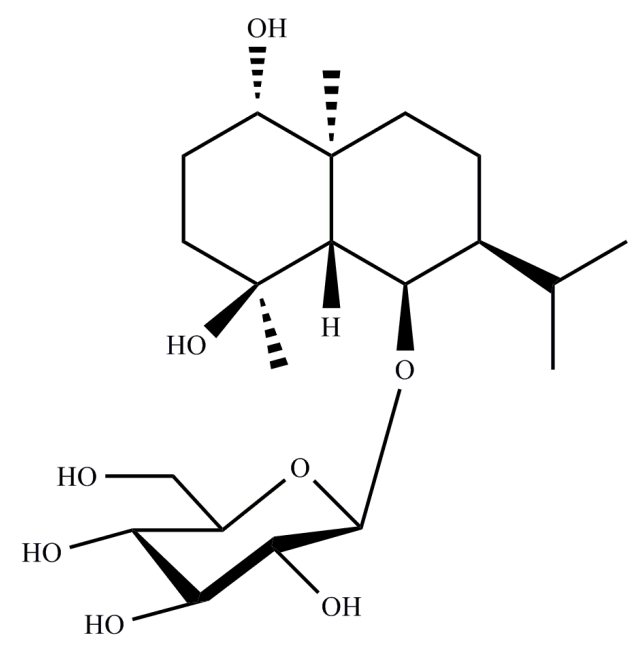

Figure 1: Chemical structure of PA

\section{Cytotoxicity of PA against BGC823 cells}

Results from MTT assay (Figure 2) indicated that PA $(5,10,15,20,25,30,35$ or $40 \mu \mathrm{g} / \mathrm{mL})$ significantly reduced the viability of BGC823 cells, relative to the untreated control $(p<0.01)$. The $\mathrm{IC}_{50}$ value of PA was $25.43 \mu \mathrm{g} / \mathrm{mL}$.

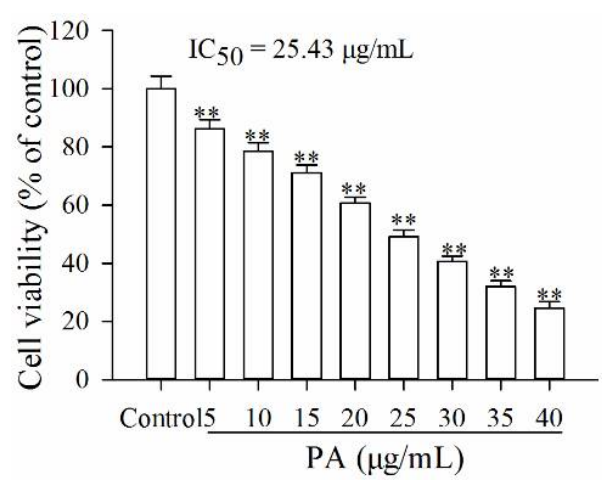

Figure 2: Cytotoxic activity of $P A$ against $B G C 823$ cells; ${ }^{* *} p<0.01$, relative to the control

\section{PA induced apoptosis in BGC823 cells}

Results from MTT assay indicated that PA exerted good cytotoxic activity against BGC823 cells. Therefore, flow cytometry analysis was carried out to see if the cytotoxicity was related to apoptosis. The results showed that PA (10, 20 or $40 \mu \mathrm{g} / \mathrm{mL}$ ) induced significant apoptosis in BGC823 cells, relative to the control $(p<0.01$; Figure 3 ). These results revealed that the cytotoxicity of PA was due to apoptosis. 

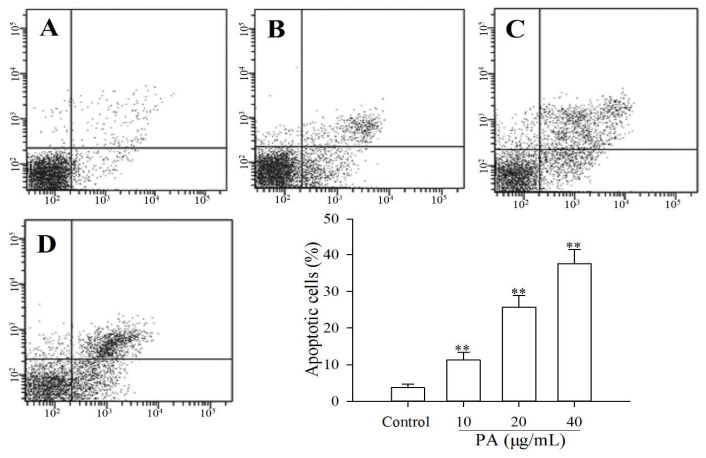

Figure 3: Apoptosis-inducing effect of PA in BGC823 cells; $A$ is control, while $B, C$ and $D$ represent 10,20 and $40 \mu \mathrm{g} / \mathrm{mL} \mathrm{PA}$, respectively; ${ }^{* *} p<0.01$, relative to the control

PA upregulated expressions of pro-apoptotic proteins in the death receptor-mediated apoptotic pathway

The expressions of the pro-apoptotic proteins (Fas, FasL, FADD, c-caspase-10 and c-caspase8) were significantly increased by $P A(10,20$ or $40 \mu \mathrm{g} / \mathrm{mL})$, relative to the control $(p<0.05,0.01$; Figure 4).
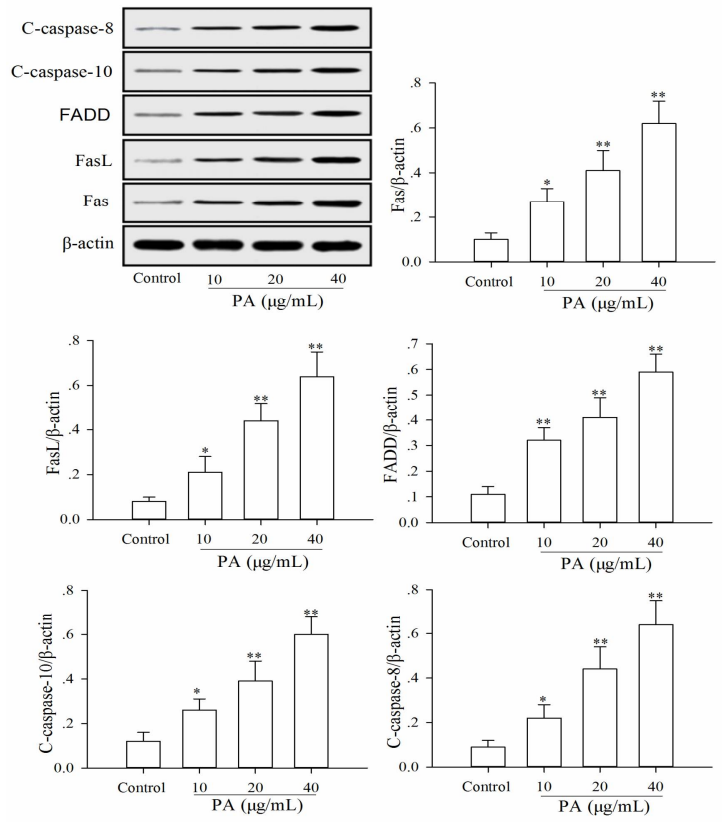

Figure 4: Up-regulatory effect of PA on Fas, FasL, FADD, c-caspase-10 and c-caspase- $8 ;{ }^{*} p<0.05,{ }^{* *} p$ $<0.01$, relative to the control

PA regulated expressions of apoptosisrelated proteins in the mitochondria-mediated apoptotic pathway

As shown in Figure 5 and Figure 6, relative to the unexposed control, PA $(10,20$ or $40 \mu \mathrm{g} / \mathrm{mL})$ significantly downregulated the anti-apoptotic proteins (survivin and $\mathrm{Bcl}-2$ ), and upregulated the pro-apoptotic proteins (Bax, Apaf-1 and Ccaspase-9) $(p<0.05,0.01)$. Moreover, PA significantly increased the release of proapoptotic proteins (Smac and cytochrome $c$ ) from mitochondria to cytoplasm $(p<0.05,0.01)$.
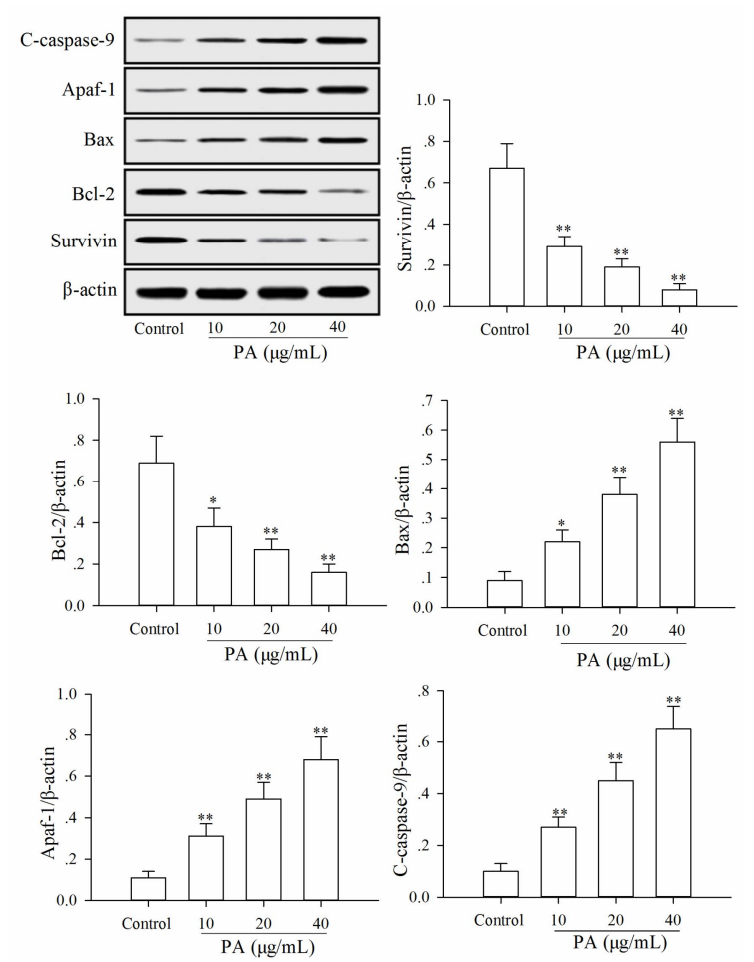

Figure 5: Regulatory effect of PA on survivin, $\mathrm{Bcl}-2$, Bax, Apaf-1 and c-caspase-9; ${ }^{*} p<0.05,{ }^{* *} p<0.01$, relative to the control

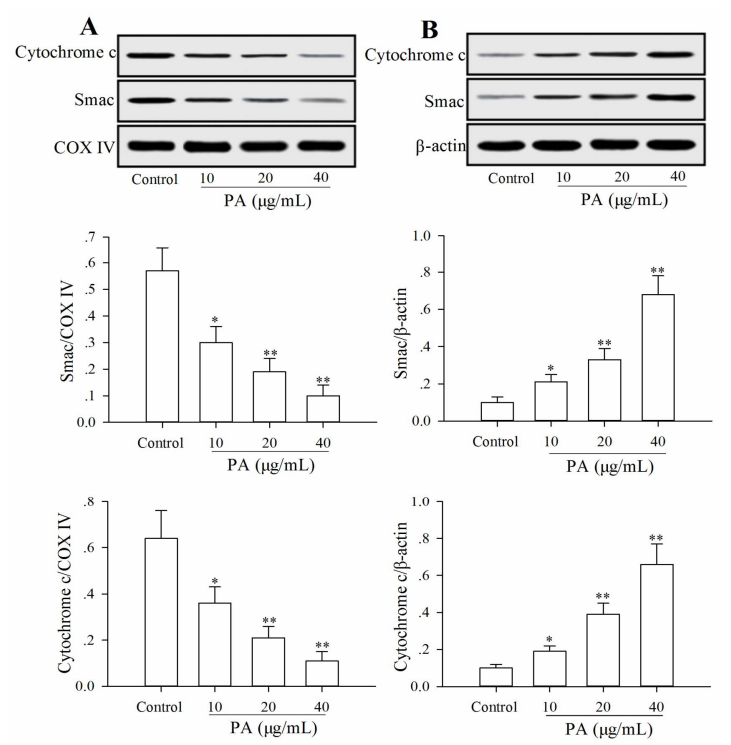

Figure 6: Positive effect of PA on release of Smac and cytochrome $c$ from mitochondria to cytoplasm; $A$ and $\mathrm{B}$ represent amounts of Smac and cytochrome $\mathrm{C}$ in mitochondria and cytoplasm, respectively; ${ }^{*} p<0.05$, ${ }^{* *} p<0.01$, relative to the control 


\section{PA increased expressions of executioner caspases}

The executioner c-caspases-3, 6 and 7 were significantly upregulated in BGC823 cells treated with PA $(10,20$ or $40 \mu \mathrm{g} / \mathrm{mL})$, relative to the control $(p<0.05,0.01$; Figure 7$)$.
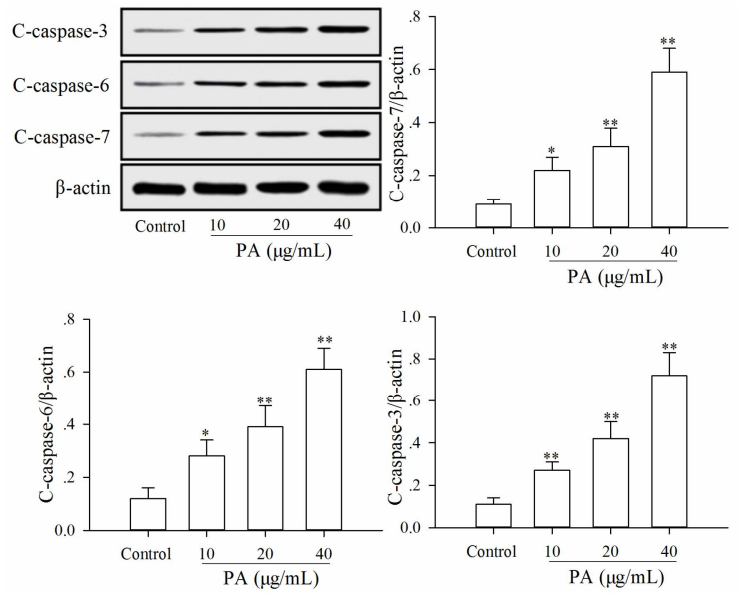

Figure 7: Up-regulatory effect of PA on executioner ccaspases-3, 6 and $7 ;{ }^{*} p<0.05,{ }^{* *} p<0.01$, relative to the control

\section{DISCUSSION}

In the present study, the cytotoxic activity of PA against BGC823 cells was related to apoptosis, and the mechanisms of action were linked to activation of death receptor- and mitochondriamediated apoptotic pathways. The MTT assay is a standard procedure for assessing the viability of cancer cells [20], while flow cytometry is used for investigating apoptosis in cancer cells [21]. The results obtained from these assay methods indicated that PA exerted good apoptosis-related cytotoxic activity against BGC823 cells.

Death receptor- and mitochondria-mediated apoptotic pathways are crucial in induction of apoptosis. Studies have suggested that ccaspases -10 and 8 , as well as Fas, FasL and FADD are essential pro-apoptotic mediators in the death receptor-mediated apoptotic pathway $[22,23]$. Following combination of death receptors such as Fas and TNFR1 with corresponding ligands such as FasL, TNF and DR4/DR5, multimerization and conformational changes in receptors are induced [24]. The interaction of death domain in death receptor of multimerization recruits FADD, and then the interaction of death effector domain in FADD promotes the combination of FADD with caspase-8 or caspase-10 [25].

Subsequently, caspase-8 or caspase-10 as a component of the death-inducing signaling complex (comprising death receptor, death ligand, FADD and caspase-8 or caspase-10) becomes activated to generate c-caspase- 8 or ccaspase-10 [26]. Then, the executioner procaspases-3, 6 and 7 are activated by c-caspase8 or c-caspase-10, resulting in executioner ccaspases-3, 6 and 7, which immediately induce cell apoptosis by acting on apoptosis-related substrates [27]. In the present investigation, PA significantly upregulated the expressions of FasL, Fas, FADD, as well as c-caspases-10, 8, 3, 6 and 7 in BGC823 cells, suggesting that the PA-associated apoptosis in BGC823 cells occurred through activation of the death receptor-mediated apoptotic pathway.

It has been established that the key proteins in mitochondria-mediated apoptotic pathway are Bcl-2, survivin, Bax, Apaf-1, cytochrome c, Smac and c-caspase-9 [28]. Cytochrome c forms apoptosome with Apaf-1, procaspase-9 and dATP, and then procaspase- 9 is activated to generate c-caspase-9 [29]. Finally, the executioner pro-caspases-3, 6 and 7 undergo activation by c-caspase- 9 to generate executioner c-caspases-3, 6 and 7, which immediately induce cell apoptosis by acting on apoptosis-related substrates [30].

The activation of executioner pro-caspases is suppressed by survivin, but the function of survivin is inhibited by Smac released from mitochondria [31]. However, Bcl-2 suppresses the release of cytochrome $\mathrm{c}$ and Smac from the mitochondria, and the function of $\mathrm{Bcl}-2$ is inhibited by Bax [32]. The results obtained in the present study showed that PA significantly upregulated the expressions of Bax and Apaf-1, as well as c-caspase- 9, 3, 6 and 7. PA increased the cytoplasmic levels of cytochrome $\mathrm{C}$ and Smac, and downregulated the expressions of survivin and Bcl-2 in BGC823 cells. These results suggest that the $\mathrm{PA}$-associated apoptosis in BGC823 cells occurred through activation of the mitochondria-mediated apoptotic pathway.

\section{CONCLUSION}

The findings of this work indicate that PA exhibits good cytotoxic activity against BGC823 cells, and the mechanisms of action are related to activation of death receptor- and mitochondriamediated apoptosis. Thus, PA has a potential for development into an anti-gastric cancer agent.

\section{DECLARATIONS}

\section{Conflict of Interest}

No conflict of interest associated with this work. 


\section{Contribution of Authors}

The authors declare that this work was done by the authors named in this article and all liabilities pertaining to claims relating to the content of this article will be borne by them. Jun Liu and Xiao Zheng conceived and designed the study, while Xiao Zheng, Jian-Wei Liang, Gang Cui and Lei Zhang performed the experiments, and collected and analyzed the data. All authors read and approved the manuscript for publication.

\section{REFERENCES}

1. Roder DM. The epidemiology of gastric cancer. Gastric Cancer 2002; 5: 5-11.

2. Tsuqane S, Sasazuki S. Diet and the risk of gastric cancer: review of epidemiological evidence. Gastric Cancer 2007; 10: 75-83.

3. Sonqun I, Putter H, Kranenbarg EM, Sasako M, van de Velde CJ. Surgical treatment of gastric cancer: 15-year follow-up results of the randomised nationwide Dutch D1D2 trial. Lancet Oncol 2010; 11: 439-449.

4. Hayashi $H$, Ochiai $T$, Shimada $H$, Gunji $Y$. Prospective randomized study of open versus laparoscopy-assisted distal gastrectomy with extraperigastric lymph node dissection for early gastric cancer. Surg Endosc 2005; 19: $1172-1176$.

5. Pang X, Wei W, Leng W, Chen Q, Xia H, Chen L, Li R. Radiotherapy for gastric cancer: a systematic review and meta-analysis. Tumor Biol 2014; 35: 387-396.

6. Berney CR, Merrett ND. Adjuvant chemradiotherapy for gastric cancer. N Engl J Med 2002; 346: 210-211.

7. Woll E, Devries A, Eisterer W, Hejna M, Keil F, Stein H, Zacherl J, Greil R. Chemotherapy in gastric cancer. Anticancer Res 2008; 28: 1213-1219.

8. Yu LY, Hu Y, Duan JH, Yang XD. A novel approach of targeted immunotherapy against adenocarcinoma cells with nanoparticles modified by CD16 and MUC1 aptamers. J Nanomater 2015; 2015: 316968.

9. Mao F, Zhang L, Cai MH, Guo H, Yuan HH. Leonurine hydrochloride induces apoptosis of H292 lung cancer cell by a mitochondria-dependent pathway. Pharm Biol 2015; 53: 1684-1690.

10. Zhang JY, Zhang G. Progress of litchi seeds on the main active ingredients and pharmacology effects. J Guandong Pharmaceut Univ 2014; 30: 792-797.

11. Lin CC, Chung YC, Hsu CP. Anti-cancer potential of litchi seed extract. World J Exp Med 2013; 3: 56-61.

12. Hsu CP, Lin CC, Huang CC, Lin YH, Chou JC, Tsia YT, Su JR, Chung YC. Induction of apoptosis and cell cycle arrest in human colorectal carcinoma by litchi seed extract. J Biomed Biotechnol 2012; 2012: 341479.

13. $X u X Y$, Xie HH, Hao J, Jiang $Y M$, Wei $X Y$. Eudesmane sesquiterpene glucosides from lychee seed and their cytotoxic activity. Food Chem 2010; 123: 1123-1126.
14. Wu JT, Lv SM, Lu CH, Gong J, An JB. Effect of 3,3'biisofraxidin on apoptosis of human gastric cancer BGC823 cells. Trop J Pharm Res 2015; 14: 1803-1811.

15. Zhou JB, Peng G, Wang J, Nie S, Li J, Jia YC, Zhang $Q Y$. Ebracteolatain $A$ and ebracteolatain $B$ induce apoptosis of human hepatoma cell line (HepG2). Trop $J$ Pharm Res 2015; 14: 1821-1828.

16. Tong $K$, Xin C, Chen $W$. Isoimperatorin induces apoptosis of the SGC 7901 human gastric cancer cell

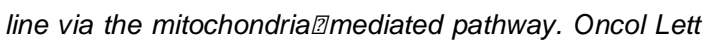
2017; 13: 518-524.

17. Dou C, Han M, Zhang B, Sun L, Jin X, Li T. Chrysotoxene induces apoptosis of human hepatoblastoma HepG2 cells in vitro and in vivo via activation of the mitochondria?mediated apoptotic signaling pathway. Oncol Lett 2018; 15: 4611-4618.

18. Zheng Z, Qiao Z, Gong R, Wang $Y$, Zhang $Y$, Ma $Y$, Zhang $L, L u Y$, Jiang $B, L i G$, et al. Uvangoletin induces mitochondria-mediated apoptosis in HL-60 cells in vitro and in vivo without adverse reactions of myelosuppression, leucopenia and gastrointestinal tract disturbances. Oncol Rep 2016; 35: 1213-1221.

19. Kitajima J, Kimizuka K, Tanaka Y. Three new sesquiterpenoid glucosides of Ficus pumila fruit. Chem Pharm Bull 2000; 48: 77-80.

20. Zhou JB, Peng G, Wang J, Nie S, Li J, Jia YC, Zhang $Q Y$. Ebracteolatain $A$ and ebracteolatain $B$ induce apoptosis of human hepatoma cell line (HepG2). Trop $J$ Pharm Res 2015; 14: 1821-1828.

21. Henry CM, Hollville E, Martin SJ. Measuring apoptosis by microscopy and flow cytometry. Methods 2013; 61: 9097.

22. Schmitz L, Kirchhoff S, Krammer PH. Regulation of death receptor-mediated apoptosis pathways. Int J Biochem Cell Biol 2000; 32: 1123-1136.

23. Ashkenazi A, Salvesen G. Related cell death: signaling and mechanisms. Annu Rev Cell Dev Biol 2014; 30: 337-356.

24. Garcia-Santos G, Martin V, Rodriquez-Blanco J, CasadoZapico S, Sanchez-Sanchez AM, Antolin I, Rodriguez C. Fas/Fas ligand regulation mediates cell death in human Ewing's sarcoma cells treated with melatonin. $\mathrm{Br} J$ Cancer 2012; 106: 1288-1296.

25. Ikner A, Ashkenazi A. TWEAK induces apoptosis through a death-signaling complex comparing receptorinteracting protein 1 (RIP1), Fas-associate death domain (FADD), and caspase-8. J Biol Chem 2011; 286: 21546-21554.

26. Young MM, Takahashi Y, Khan O, Park S, Hori T, Yun J, Sharma AK, Amin S, Hu CD, Zhang J, Kester M, Wang HG. Autophagosomal membrane served as platform for intracellular death-inducing signaling complex (iDISC)medicated caspase-8 activation and apoptosis. J Biol Chem 2012; 287: 12455-12468.

27. Boucher D, Duclos C, Denault JB. General in vitro caspase assay procedures. Methods Mol Biol 2014; 1133: 3-39. 
28. Shi YG. A structural view of mitochondria-mediated apoptosis. Nat Struct Biol 2001; 8: 394-401.

29. Yuan S, Akey CW. Apoptosome structure, assembly, and procaspase activation. Structure 2013; 21: 501-515.

30. Slee $E A$, Harte $M T$, Kluck RM, Wolf $B B$, Casiano $C A$, Newmeyer DD, Wang HG, Nicholson DW, Alnemri ES, Green DR, Martin SJ. Ordering the cytochrome cinitiated caspase cascade: hierarchical activation of caspases-2, -3, -6, -7, -8, and -10 in a caspase-9dependent manner. J Cell Biol 1999; 144: 281-292.
31. Zhao YC, Wang Y, Ni XJ, Li Y, Wang XM, Zhu YY, Luo CY. Clinical significance of Smac and survivin expression in breast cancer patients treated with anthracycline-based neoadjuvant chemotherapy. Mol Med Rep 2014; 9: 614-620.

32. Renault TT, Teijido O, Antonsson B, Dejean LM, Manon S. Regulation of Bax mitochondrial localization by $\mathrm{Bcl}-2$ and $B c l-x(L)$ : keep your friends close but your enemies closer. Int J Biochem Cell Biol 2013; 45: 64-67. 